19 Revue d'histoire du XIXe siècle

Société d'histoire de la révolution de 1848 et des

révolutions du XIXe siècle

$12 \mid 1996$

L'incendie

\title{
Incendiaire ou pyromane? Médecins et juges face à l'incendie volontaire
}

Jean-Jacques Yvorel

\section{OpenEdition \\ Journals}

Electronic version

URL: http://journals.openedition.org/rh19/85

DOI: $10.4000 /$ rh 19.85

ISSN: 1777-5329

Publisher

La Société de 1848

Printed version

Date of publication: 1 June 1996

ISSN: 1265-1354

Electronic reference

Jean-Jacques Yvorel, « Incendiaire ou pyromane ? Médecins et juges face à l'incendie volontaire », Revue d'histoire du XIXe siècle [Online], 12 | 1996, Online since, connection on 20 April 2019. URL : http://journals.openedition.org/rh19/85; DOI : 10.4000/rh19.85

This text was automatically generated on 20 April 2019

Tous droits réservés 


\title{
Incendiaire ou pyromane?
} Médecins et juges face à l'incendie volontaire

\author{
Jean-Jacques Yvorel
}

\section{ABSTRACTS}

No abstract available by now

Pas de résumé disponible actuellement

INDEX

Mots-clés: Incendie 